\title{
Antimicrobial Activity of Herbal Toothpaste against Organisms Causing Dental Caries
}

\author{
M. Shailaja Raj ${ }^{1}$, R. Hema ${ }^{1 *}$ and Anitha Thomas ${ }^{1}$ \\ ${ }^{1}$ Department of Microbiology, St. Francis College for Women, Hyderabad, India.
}

Authors' contributions

This work was carried out in collaboration among all authors. All authors read and approved the final manuscript.

Article Information

DOI: $10.9734 / A R R B / 2020 / v 35 i 1230313$
Editor(s):
(1) Dr. Paola Angelini, University of Perugia, Italy.
Reviewers:

(1) Ashwaq M. S. Aljbouri, University of Babylon, Iraq.

(2) Fiatun Hanifah Ramadhan, S. Farm, STIKES Al-Irsyad Al-Islamiyyah Cilacap, Indonesia.

Complete Peer review History: http://www.sdiarticle4.com/review-history/63632

Original Research Article

Received 28 September 2020

Accepted 02 December 2020

Published 14 December 2020

\section{ABSTRACT}

Aim: Dental caries occurs as a result of acid produced by bacteria which destroys the enamel and underlying dentin. A study was carried out to isolate microorganisms that cause dental caries in patients belonging to different age groups and find out the antimicrobial activity of various toothpastes against them.

Study Design: Collection of samples for isolation of caries causing organisms, to identify them using biochemical tests and test the activity of herbal toothpastes against them.

Place and duration of study: Samples were collected from Krish Multispeciality Clinic and Prashanth Dental Clinic, Nagole between June'2016 - December'2017 and worked on, at Microbiology Department, St. Francis College for women, Hyderabad.

Methodology: Ten samples of each age group from 10-20 yrs., 20-40 yrs. and 40-60 yrs. were isolated. The organisms were identified by carrying out various biochemical tests according to Bergey's Manual of Systematic Bacteriology and molecular characterization based on 16s rRNA typing. Identified organisms were used to test the antimicrobial activity of herbal toothpastes by employing agar well diffusion method. ANOVA is used for statistical analysis.

Results and Conclusion: Patanjali herbal products like Dantkanti are gaining lot of importance and have become a part of life of common man because of their effectivity. Our studies revealed that out of the various toothpastes tested, Patanjali toothpaste had good antimicrobial activity against all the 
isolates. On comparative analysis of f-ratio and $\mathrm{P}$ significant value $(<.05$.) of all pairs, it is observed that Patanjali has good antimicrobial activity against all isolates tested. The efficacy of Meswak is almost similar to that of Patanjali.

Keywords: Dental caries; herbal toothpaste; Klebsiella pneumoniae.

\section{INTRODUCTION}

Dental plaque is a biofilm which is pale yellow in color that develops naturally on the teeth. A dental plaque is formed by colonizing bacteria trying to attach themselves to the tooth surface [1]. This dental plaque gives rise to dental caries. Dental caries denotes the decay or destruction of tooth. It is caused by specific types of bacteria [2]. Four important factors play a role in formation of caries. They are: a tooth surface (enamel or dentin), caries-causing bacteria, fermentable carbohydrates such as sucrose and time [3]. The bacteria produce acid that destroys the tooth enamel and the layer under it, the dentin. Many different types of bacteria normally live in the human mouth [2]. But only a few specific species of bacteria are believed to cause dental caries [4]. The most common bacteria associated with dental cavities are the Streptococcus mutans, Streptococcus sobrinus, and Lactobacilli [5]. They build up on the teeth a sticky film called plaque [2]. Though the plaque is usually associated with the oral diseases which include cavities and other gum diseases, its construction is normal which cannot be prevented. These dental biofilms can be quite serious as their acidic nature causes the demineralization of the teeth resulting in the formation of calculus which is also known as tartar. These are hardened structures that require professional cleaning as they cannot be removed by tooth brush. It is therefore very essential to eradicate these dental plaques to avoid the formation of dental caries and related gum disease $[6,7]$.

To remove plaque and maintain dental hygiene agents like toothpaste and various mouth washes can be used. Toothpaste is a dentifrice which improves the aesthetic appearance and health of the teeth. Toothpaste is commonly used for promotion of oral hygiene, removal of dental plaque and food debris from the mouth [8]. Mechanical plaque removal is one of the most accepted methods of controlling plaque and gingivitis. Several chemical preventive agents have beneficial effects in the control of plaque and to reduce or prevent oral disease. Hence, various chemical formulations were tried in dentifrices [9]. Chemicals, mainly triclosan and chlorhexidine, have been added in mouth rinses and dentifrices to prevent plaque and gingivitis. But some of these substances show undesirable side effects such as tooth staining and altered taste $[10,11]$. This led to increased attention on using natural ingredients in herbal dentifrices. Herbal dentrifices like Colgate herbal, Meswak, Dabur red, Neem clove, spearmint herbal are made using sage, chamomile, Echinacea, myrrh, peppermint oil etc. These ingredients have several benefits; chamomile has antiinflammatory effect, echinacea has immune stimulatory property, sage and rhatany have antihemorrhagic properties, myrrh is a natural antiseptic, and peppermint oil has analgesic, antiseptic, and anti-inflammatory properties [12] Using above herbal ingredients several toothpastes are manufactured and released into the market. Some of them like Colgate herbal, Dabur red, Himalaya complete care, Neem clove paste, Meswak and Dantkanti have gained a lot of importance. Various studies were conducted to assess the antimicrobial activity of these toothpastes. Results of such studies have proved that herbal toothpastes are very efficient in maintaining the oral hygiene. Dabur red containing the following: Pudinasatva, Tomarbeej and laungkatelis is as effective as the conventional non-herbal toothpaste in plaque reduction and reduction of gingivitis [13]. Meswak is a herbal dentifrice containing the pure extract of the Meswak plant Salvadora persica, the famous "Toothbrush Tree" which has been used for centuries. The astringent and antibacterial properties of Meswak help reduce tooth decay, fight plaque, and prevent gum diseases [14].

Patanjali dantkanti is a herbal toothpaste made using different components like Akarkara Anacyclus Pyrethrum, Babul (Kikar) - Acacia Arabica, Tomar - Zanthoxylum Alatum, Neem Azadirachta indica, Pudina (Spearmint) - (Clove) - Syzygium Aromaticum, Pippali (Long Pepper) Piper Longum, Vajradanti - Barleria Prionitis etc. The above herbal ingredients are known to have antibacterial, anti-inflammatory and anticariogenic properties. It is observed that the herbal toothpaste (Dantkanti) is effective when compared to the conventional toothpaste in 
maintenance of oral hygiene and reduction of gum bleeding [15]. It gives protection and long life to teeth and fights against dental problems.

\section{MATERIALS AND METHODS}

\subsection{Sample Collection}

The samples were collected from patients suffering with dental caries, from Krish dental clinic and Prashanth dental clinic, Nagole, Hyderabad. Sterile cotton swabs were placed at site of infection for few minutes and then inoculated into sterile nutrient broth. The tubes were properly labeled with patient's age and gender. These samples were stored at $4^{\circ} \mathrm{C}$.

\subsubsection{Growth media for isolation of organisms}

For isolation of dental caries causing bacteria, nutrient agar was used. A loopful of sample was streaked on the nutrient agar plate and the plates were incubated at $37^{\circ} \mathrm{C}$ for $24 \mathrm{~h}$.

\subsubsection{Cultural and morphological characters}

The colony morphology of different samples was observed. The bacteria were gram stained.

\subsubsection{Biochemical properties}

Biochemical properties of isolates were used in identification of the organisms. Different biochemical tests like IMViC, glucose fermentation, mannitol fermentation, nitrate reduction, catalase, oxidase tests were carried out based on the Bergey's manual of systematic bacteriology. All the chemicals and reagents used were of analytical grade.

\subsubsection{Molecular method of identification (16S rRNA typing)}

16 ribosomal RNA (or 16S rRNA) is the component of the $30 \mathrm{~S}$ small subunit of a prokaryotic ribosome that binds to the ShineDalgarno sequence. The genes coding for it are referred to as 16S rRNA gene and are used in reconstructing phylogeny, due to the slow rates of evolution of this region of the gene [16]. The DNA of the sample was isolated and 16s DNA fragment was amplified using PCR. The consensus sequence of amplicon was generated and analyzed by using BLAST in NCBI.

\subsection{Assessing the Antimicrobial Activity of Toothpastes}

Agar well diffusion method was used for antimicrobial studies. Nutrient agar plates were prepared. $0.1 \mathrm{ml}$ of culture was seeded and then wells were bored. Into each well $0.3 \mathrm{gm}$ of test toothpastes were added. Antimicrobial activity of each toothpaste was determined by measuring the zones of inhibition.

\subsubsection{Statistical tool}

ANOVA was used to determine $p$ value, $f$ ratio and the comparative analysis of toothpastes was done using this tool.

\section{RESULTS}

30 samples were collected from patients belonging to the age groups 10-20, 20-40, 40-60 yrs. The samples were labelled as S1, S5, S6, S8, S9, S10, S12, S13, S14, S16, S17, S18, $\mathrm{S} 20, \mathrm{~S} 22, \mathrm{~S} 25, \mathrm{~S} 26, \mathrm{~S} 28, \mathrm{~S} 29, \mathrm{~S} 30$, S31.Biochemical characterization was carried out against the isolates of 10-20 yrs age group. Based on the various biochemical tests, out of the ten samples isolated the organisms belonged to gram negative are identified to be of Pseudomonas sps, Aeromonas sps and grampositive nature were identified to be of Staphylococcal sps, Bacillus sps, as shown in Table 1.

According to various biochemical tests carried out against the isolates of 20-40 yrs the organisms of gram positive nature were identified as Bacillus sps and those of gram-negative nature are identified as Aeromonas sps, Pseudomonas sps, Klebsiella sps, Serratia sps as shown in Table 2.

Based on the various biochemical tests carried out among the samples isolated from 40-60 yrs age group, the gram-positive organisms are found to be of Bacillus sps, Micrococcus sps and the gram negative ones are found to be Pseudomonas sps and Citrobacter sps. The results are shown in Table 3. 
Table 1. Biochemical characterization of isolates from patients in the age group of 10-20 yrs

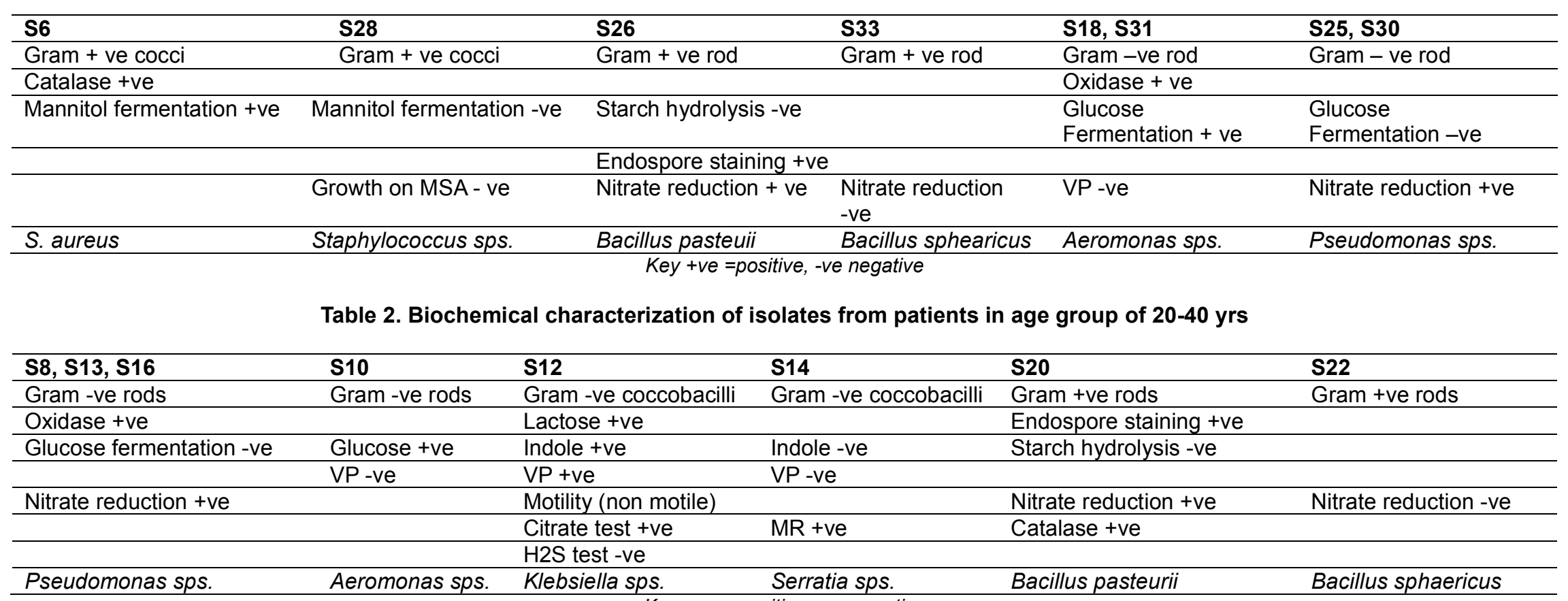

Key, +ve = positive, -ve negative 
Table 3. Biochemical characterization of isolates from patients in age group of 40-60 yrs

\begin{tabular}{|c|c|c|c|}
\hline S1, S5 & S17 & $\mathbf{S 2 9}$ & S9 \\
\hline Gram +ve rods & Gram +ve cocci & Gram -ve rods & Gram -ve coccobacilli \\
\hline Endospore staining +ve & Mannitol fermentation -ve & Oxidase +ve & Lactose fermentation +ve \\
\hline Catalase +ve & & & Indole Test +ve \\
\hline Starch Hydrolysis -ve & Growth on MSA & & Citrate test +ve \\
\hline Nitrate reduction +ve & & Nitrate reduction +ve & VP test -ve \\
\hline & Glucose fermentation +ve & Glucose fermentation -ve & \\
\hline Bacillus pasteurii & Micrococcus varians & Pseudomonas sps. & Citrobacter diversus \\
\hline
\end{tabular}




\subsection{6s rRNA Typing of S12}

The gene sequence for 16s rRNA region of S12 sample was isolated, amplified and analyzed using BLAST. It was identified to have $99 \%$ identity with K. pneumoniae strain DSM 30104.

\subsubsection{Sanger sequence chromatogram file data}

>Forward Sequence data

TGAGGCGTGAGCTTCCGCGAGCTAACGCAG TTAAATCGACCGCCTGGGGAGTACGGCCGCA AGGTTAAAACTCAAATGAATTGACGGGGGCC CGCACAAGCGGTGGAGCATGTGGTTTAATTC GATGCAACGCGAAGAACCTTACCTGGTCTTG ACATCCACAGAACTTTCCAGAGATGCATTGGT GCCTTCGGGAACTGTGAGACAGGTGCTGCAT GGCTGTCGCAGCTCGTGTTGTGAAATGTTGG GTTAAGTCCCGCAACGAGCGCAACCCTTATC CTTTGTTGCCAGCGGTTCGGCCGGGAACTCA AAGGAGACTGCCAGTGATAAACTGGAGGAAG GTGGGGATGACGTCAAGTCATCATGGCCCTT ACGACCAGGGCTACACACGTGCTACAATGGC ATATACAAAGAGAAGCGACCTCGCGAGAGCA AGCGGACCTCATAAAGTATGTCGTAGTCCGG ATTGGAGTCTGCAACTCGACTCCATGAAGTC GGAATCGCTAGTAATCGTAGATCAGAATGCTA CGGTGAATACGTTCCCGGGCCTTGTACACAC CGGCCGTCACACCATGGGAGTGGGTTGCAA AAGAAGTAGGTAGCTTAACCTTCTG GAGGGCGCTTACCACTTTGTGATTCATGACT GGGGTGAAGTCGTA

\section{>S_12 consensus sequence \\ TGÄGGCGTGAGCTTCCGCGAGCTAACGCAG TTAAATCGACCGCCTGGGGAGTACGGCCGCA AGGTTAAAACTCAAATGAATTGACGGGGGCC CGCACAAGCGGTGGAGCATGTGGTTTAATTC GATGCAACGCGAAGAACCTTACCTGGTCTTG ACATCCACAGAACTTTCCAGAGATGCATTGGT GCCTTCGGGAACTGTGAGACAGGTGCTGCAT GGCTGTCGTCAGCTCGTGTTGTGAAATGTTG GGTTAAGTCCCGCAACGAGCGCAACCCTTAT CCTTTGTTGCCAGCGGTTCGGCCGGGAACT CAAAGGAGACTGCCAGTGATAAACTGGAGGA AGGTGGGGATGACGTCAAGTCATCATGGCCC TTACGACCAGGGCTACACACGTGCTACAATG GCATATACAAAGAGAAGCGACCTCGCGAGAG CAAGCGGACCTCATAAAGTATGTCGTAGTCC GGATTGGAGTCTGCAACTCGACTCCATGAAG TCGGAATCGCTAGTAATCGTAGATCAGAATGC TACGGTGAATACGTTCCCGGGCCTTGTACAC ACCGGCCGTCACACCATGGGAGTGGGTTGC AAAAGAAGTAGGTAGCTTAACCTTCTG GAGGGCGCTTACCACTTTGTGATTCATGACT GGGGTGAAGTCGTA}

Blast report is shown in Table 4.

\subsection{Comparative Analysis of Antimicrobial Activity of Patanjali and other Herbal Toothpastes}

Agar well diffusion method was used. Four toothpastes- Patanjali dantkanti, Colgate herbal, Meswak and Dabur red were used against few isolates to determine their antimicrobial activity. The zones of inhibition around each toothpaste are observed as shown in Table 5.

The results from Table 5 indicate that all tested toothpastes demonstrated a significant antimicrobial activity against the tested microorganisms $(P<0.05)$. The antimicrobial activity of patanjali toothpaste against the organisms S1, S3, S6, S12, S25, S20 and Streptococcus mutans was very significant. The activity of Meswak was similar to the activity of Patanjali against S6, S12, S20. Meswak though effective against other organisms S1, S3, S25 and $S$. mutans but was not as effective as Patanjali. Meswak and Patanjali were very effective against all the organisms tested than Dabur $(P<0.05)$, and colgate herbal $(P<0.05)$. The data analyzed using ANOVA showed no significant difference among Meswak and Patanjali with respect to their antimicrobial activities $(P>0.05)$.

There is a significant difference in the antimicrobial activities of Patanjali and Dabur. The $f$-ratio value is 10.85303 . The $P$-value is .006407 . The result is significant at $P<.05$.

Patanjali and Colgate Herbal The $f$-ratio value is 11.53643. The $P$-value is .005304 . The result is significant at $P<.05$.

Meswak and Dabur The $f$-ratio value is 7.57293 . The $P$-value is .017541 . The result is significant at $P<.05$.

Meswak and Colgate Herbal The $f$-ratio value is 8.32574. The $P$-value is .013692 . The result is significant at $P<.05$.

The results of antimicrobial activity of 4 test toothpastes against S1, S6 and S12 are shown in Figs. 3, 4, 5 respectively. The antimicrobial activity of the 4 test toothpastes against Streptococcus mutans is shown in Fig. 6. 
Table 4. Blast report

\begin{tabular}{|c|c|c|c|c|c|c|}
\hline Description & $\begin{array}{l}\text { Max } \\
\text { Score }\end{array}$ & $\begin{array}{l}\text { Total } \\
\text { Score }\end{array}$ & $\begin{array}{l}\text { Query } \\
\text { Cover }\end{array}$ & $\begin{array}{l}\text { E } \\
\text { value }\end{array}$ & Identity & $\begin{array}{l}\text { Accession } \\
\text { number }\end{array}$ \\
\hline $\begin{array}{l}\text { Klebsiella pneumoniae strain DSM } \\
3010416 S \text { rRNA gene, partial } \\
\text { sequence }\end{array}$ & 1177 & 1177 & $100 \%$ & 0 & $99 \%$ & NR_117686.1 \\
\hline $\begin{array}{l}\text { Klebsiella pneumoniae strain DSM } \\
3010416 \text { S rRNA gene, partial } \\
\text { sequence }\end{array}$ & 1177 & 1177 & $100 \%$ & 0 & $99 \%$ & NR_117683.1 \\
\hline $\begin{array}{l}\text { Klebsiella pneumoniae strain DSM } \\
3010416 S \text { rRNA gene, complete } \\
\text { sequence }\end{array}$ & 1177 & 1177 & $100 \%$ & 0 & $99 \%$ & NR_036794.1 \\
\hline $\begin{array}{l}\text { Klebsiella pneumoniae strain DSM } \\
3010416 S \text { rRNA gene, partial } \\
\text { sequence }\end{array}$ & 1173 & 1173 & $100 \%$ & 0 & $99 \%$ & NR_114715.1 \\
\hline $\begin{array}{l}\text { Klebsiella pneumoniae strain DSM } \\
3010416 \text { S rRNA gene, partial } \\
\text { sequence }\end{array}$ & 1171 & 1171 & $100 \%$ & 0 & $99 \%$ & NR_117684.1 \\
\hline $\begin{array}{l}\text { Klebsiella pneumoniae strain NBRC } \\
1494016 \text { S rRNA gene, partial } \\
\text { sequence }\end{array}$ & 1168 & 1168 & $99 \%$ & 0 & $99 \%$ & NR_113702.1 \\
\hline $\begin{array}{l}\text { Klebsiella pneumoniae strain DSM } \\
3010416 S \text { rRNA gene, partial } \\
\text { sequence }\end{array}$ & 1166 & 1166 & $100 \%$ & 0 & $99 \%$ & NR_117685.1 \\
\hline $\begin{array}{l}\text { Klebsiella pneumoniae strain DSM } \\
3010416 S \text { rRNA gene, partial } \\
\text { sequence }\end{array}$ & 1166 & 1166 & $100 \%$ & 0 & $99 \%$ & NR_117682.1 \\
\hline $\begin{array}{l}\text { Klebsiella pneumoniae strain JCM } \\
166216 S \text { rRNA gene, partial } \\
\text { sequence }\end{array}$ & 1162 & 1162 & $98 \%$ & 0 & $99 \%$ & NR_113240.1 \\
\hline $\begin{array}{l}\text { Klebsiella quasi pneumoniae subsp. } \\
\text { Simili pneumoniae strain 07A044 16S } \\
\text { rRNA gene, partial sequence }\end{array}$ & 1157 & 1157 & $98 \%$ & 0 & $99 \%$ & NR_134063.1 \\
\hline
\end{tabular}

Table 5. Antimicrobial activity of herbal tooth paste against the dental isolates

\begin{tabular}{llllll}
\hline S.no. & Sample & Patanjali & Dabur red & Colgate herbal & Meswak \\
\hline 1. & S1 & $60 \mathrm{~mm}$ & $35 \mathrm{~mm}$ & $37 \mathrm{~mm}$ & $50 \mathrm{~mm}$ \\
2. & S3 & $37 \mathrm{~mm}$ & $15 \mathrm{~mm}$ & 0 & $31 \mathrm{~mm}$ \\
3. & S6 & $30 \mathrm{~mm}$ & 0 & 0 & $30 \mathrm{~mm}$ \\
4. & S12 & $43 \mathrm{~mm}$ & 0 & 0 & $43 \mathrm{~mm}$ \\
5. & S25 & $41 \mathrm{~mm}$ & $35 \mathrm{~mm}$ & $30 \mathrm{~mm}$ & $34 \mathrm{~mm}$ \\
6. & S20 & $35 \mathrm{~mm}$ & $28 \mathrm{~mm}$ & $28 \mathrm{~mm}$ & $35 \mathrm{~mm}$ \\
7. & Streptococcus mutans & $45 \mathrm{~mm}$ & $23 \mathrm{~mm}$ & $25 \mathrm{~mm}$ & $34 \mathrm{~mm}$ \\
\hline
\end{tabular}

\section{DISCUSSIONS}

In this study 30 samples were collected from patients suffering with dental caries, belonging to different age groups. The samples were categorized into 3 groups based on the patient's age (10-20 yrs, 20-40yrs and 40-60 yrs). These samples were plated onto nutrient agar and sub cultured in nutrient broth. Various biochemical tests like Indole, glucose fermentation, nitrate reduction etc were carried out to identify the organisms, according to Bergey's manual of systematic bacteriology. Group of 10-20 yrs organisms like Staphylococcus aureus, Aeromonas sps, Pseudomonas sps, Bacillus pasteurii, Bacillus sphaericus were identified. Group of 20-40 yrs- organisms like Pseudomonas sps, Aeromonas sps, Bacillus sps like B.sphaericus, B. alvei, B.polymyxa, Klebsiella sps, Serratia sps were identified. Group of 40-60 yrs- organisms like Citrobacter diversus, Microccus varians, Pseudomonas sps, Bacillus pasteurii were identified. 


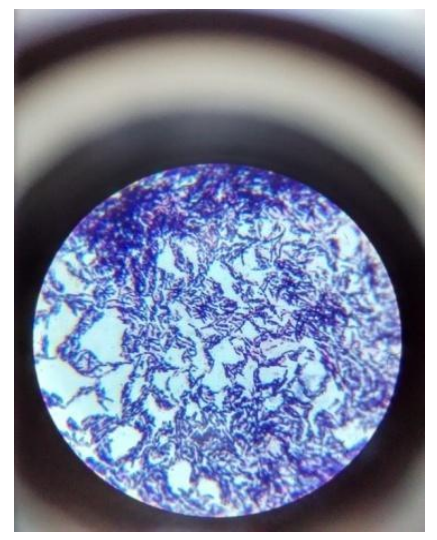

Fig. 1. Gram staining field view of S1

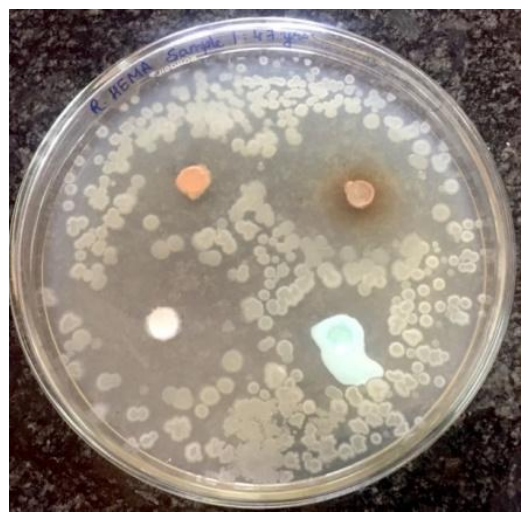

Fig. 3. Antimicrobial activity against $\mathrm{S} 1$

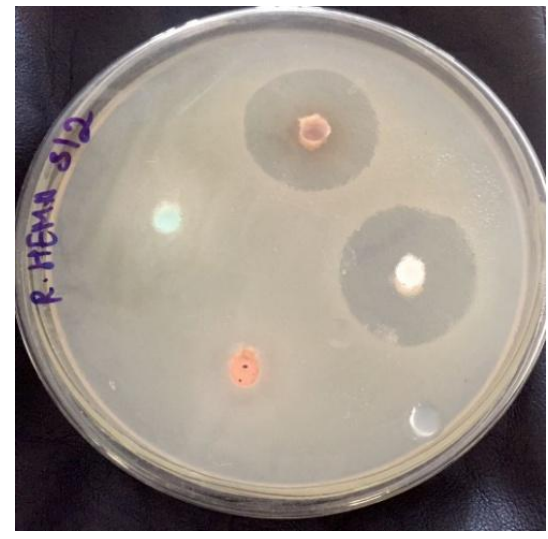

Fig. 5. Antimicrobial activity against $\mathrm{S} 12$

Studies suggest that $S$. aureus continues to be a frequent isolate in the oral cavity and perioral region and is mostly due to cross-infection [17]. Aeromonas sps is known to cause gasteroentiritis and also pneumonia in humans [18]. This may be reason behind its presence in

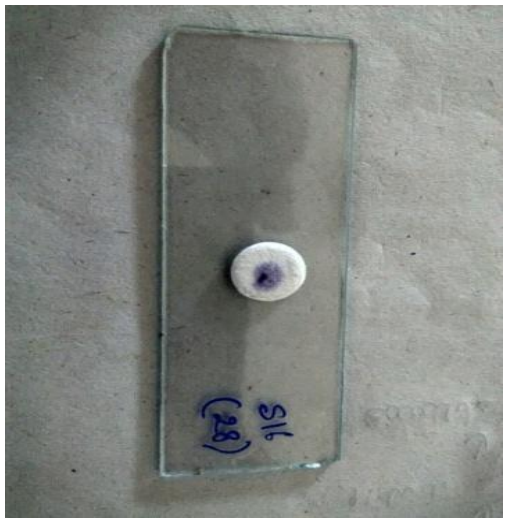

Fig. 2. Oxidase test of S16

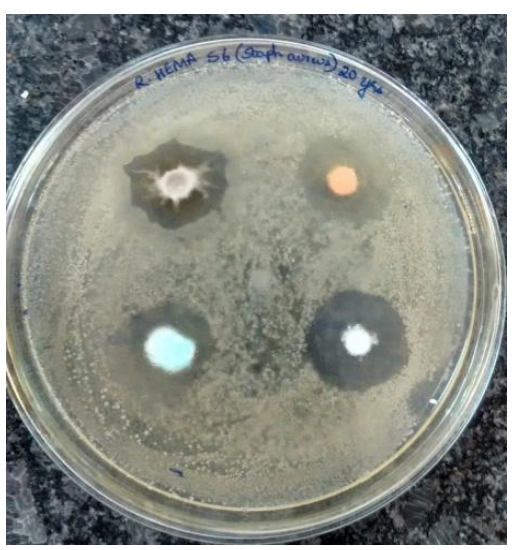

Fig. 4. Antimicrobial activity against S6

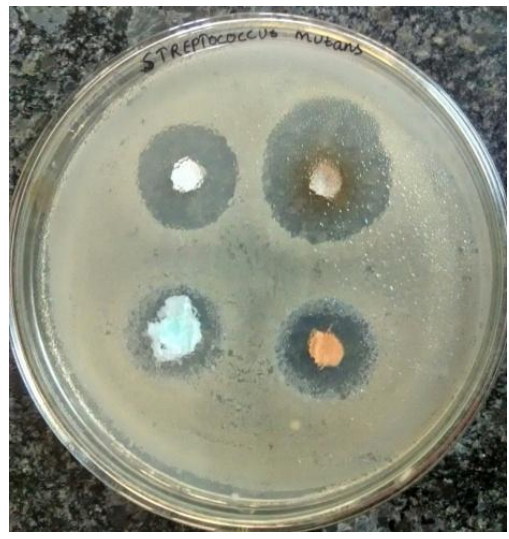

Fig. 6. Antimicrobial activity against S.mutans

oral cavity. Pseudomonas sps cause nosocomial infections. They act as opportunistic pathogens and many strains are isolated from dental unit water lines [19]. This shows that Pseudomonas $s p s$ are associated with dental infections. Bacillus sps are a major part of normal flora of 
humans and are also mostly used in different probiotic products. During their consumption the bacteria may colonize the oral cavity and also Lactobacilli are known to be associated with dental caries [20]. Citrobacter sps are major nosocomial pathogens. In a study conducted to detect quorum sensing among bacteria, Citrobacter sps were isolated from dental plaque [21]. Micrococcus sps were known to be associated with dental caries and various antimicrobial agents' activity is assessed against them [22]. Klebsiella sps are important opportunistic hospital acquired pathogens [23]. Serratia sps are nosocomial pathogens and were also found in dental unit water lines [24]. Gram negative cocci form a major role in formation of dental pellicle. After the attachment of gram positive cocci, pathogenic gram negative cocci along with other rods form colonies called corncobs which assist organisms like Streptococcus mutans in their pathogenic function $[25,26]$. The organisms identified can cause dental caries.

Though some of the organisms are a part of normal flora, when there is an imbalance in oral environment, they can cause dental caries. Therefore, removal of plaque to prevent the colonization of caries causing microbes and maintaining oral hygiene is very important. According to studies conducted by Kuldeep et al., 2016 the patients using herbal Dantkanti toothpaste have been protected effectively in terms of reduction of debris, calculus and gingival index factor is statistically significantly low. No adverse reactions of dentifrices products were observed during the trial. Hence antimicrobial studies were done with herbal tooth paste like Patanjali, Dabur, Colgate herbal and Meswak [27]. The zones of inhibition produced around the wells with different toothpastes are as shown in Table 5. Dantkanti has shown good antimicrobial activity against the different isolates, Meswak has also shown good activity like that of Dantkanti. Dabur red and Colgate herbal have shown moderate activity when compared to the other two toothpastes. Several studies have been carried out to test the antimicrobial activity of different herbal toothpastes and few of them like Colgate herbal, Dabur red and Meswak have shown moderate activity against Streptococcus mutans and other caries causing organisms [28]. The S. mutans culture used in present study belongs to strain MTCC 890 procured from IMTECH, Chandigarh.
The data analyzed using ANOVA shows significant antimicrobial activity of Patanjali toothpaste against all the isolates tested. In oneway ANOVA performed with pairs of toothpaste: Patanjali and Colgate Herbal, Patanjali and Dabur, Meswak and Dabur, Meswak and Colgate Herbal, the f-ratio and p-value derived show the significant antimicrobial activity of Patanjali \& Meswak respectively. Though the activity of Meswak is almost similar to that of Patanjali, it is noticed that the antimicrobial activity of Dabur and Colgate Herbal toothpastes vary hugely in comparison. Similar statistical analysis was performed among herbal toothpastes against S.mutans and observed that the antimicrobial activity of Patanjali was significant followed by Meswak and Dabur [29].

\section{CONCLUSION}

The mouth is a favorable habitat for a number of organisms due to the presence of nutrients and secretions. These organisms attach, colonize and accumulate on tooth surface giving rise to dental plaque [30]. Such colonizing bacteria gradually cause dental caries. Several organisms causing dental caries like Staphylococcus sps, Bacillus sps, Citrobacter sps, Micrococcus sps, Pseudomonas sps, Aeromonas sps etc have been isolated and identified in the samples collected from patients of different age groups. Among age group of 10-20 yrs different organisms were identified. Staphylococcus was identified only in the samples of this age group. This is in agreement with "A growing evidence suggests that Staphylococci can be frequently isolated from the oral cavity of particular patient groups such as children, elderly and some groups with systemic diseases." [31]. Age group of 20-40 yrs: Pseudomonas sps was identified in 3 samples falling in the range of 28-34 yrs. The samples of this age group have shown the presence of diverse variety of organisms. Age group of 40-60 yrs: Gram negative cocci predominated in this group; out of the 10 samples five of them were identified to be gram negative cocci.

Among the 4 toothpastes subjected to agar well diffusion method to determine their antimicrobial activity in this assay (Colgate herbal, Meswak, Dantkanti and Dabur red) Patanjali Dantkanti has shown the highest activity against different isolates and also the most common caries causing organism i.e, Streptococcus mutans. Meswak has also shown good activity like that of Dantkanti. Dabur red and Colgate herbal have shown moderate activity when compared to the 
other two toothpastes. Statistical analysis performed between the toothpaste samples also confirmed the higher efficacy of Patanjali Dantkanti followed by Meswak, Dabur red and Colgate herbal.

\section{ETHICAL APPROVAL}

It is not applicable.

\section{ACKNOWLEDGEMENTS}

We express our heartfelt gratitude to management of St.Francis College for Women for all the encouragement and facilities rendered in our work.

We also express our sincere thanks to Dr. Roselin, Dept of Microbiology, St. Francis College for Women for helping us with the statistical analysis.

\section{COMPETING INTERESTS}

Authors have declared that no competing interests exist.

\section{REFERENCES}

1. Becker MR, Paster BJ, Leys EJ, Moeschberger ML, Kenyon SG, Galvin JL, Griffen AL. Molecular analysis of bacterial species associated with childhood caries. Journal of Clinical Microbiology. 2002;40(3):1001-1009.

2. Article reviewed by faculty of Columbia University College of dental medicineDental Caries-Details on dental cavities. Available:www.colgate.com/en/us/oc/oralhealth/conditions/cavities/.../dental-cariescavities

3. Southam JC, Soames JV. Dental caries. oral pathology $2^{\text {nd }}$ edition. 1993;2622;14-5.

4. Hardie JM. The microbiology of dental caries. Dental update. 1982;9(4):199.

5. Marsh, Philip D, Head, David A, Devine, Deirdre A. Dental plaque as a biofilm and a microbial community-Implications for treatment. Journal of Oral Biosciences. 2015;57(4):185-191.

6. Wolf $\mathrm{H}$, Hassell T. Color atlas of dental hygiene, Thieme (New York, 333 Seventh Avenue,); 2006.

7. Verkaik MJ, Busscher HJ, Jager D, Slomp AM, Abbas F, van der Mei HC. Efficacy of natural antimicrobials in toothpaste formulations against oral biofilms in vitro. Journal of dentistry. 2011;39(3):218224.

8. Nwakanma C, Ejim CJ, Unachukwu MN. The Effects of selected toothpaste on the microbial flora of the mouth of GOU Student. International Journal of Current Microbiology and Applied Sciences. 2014; 3(9):785-792.

9. George J, Hegde S, Rajesh KS, Kumar A. The efficacy of herbal-based toothpaste in the control of plaque and gingivitis: A clinico-biochemical study. Indian Journal of Dental Research.2009;20(4):480.

10. Barnes VM, Richter R, DeVizio W. Comparison of the short-term antiplaque/antibacterial efficacy of two commercial dentifrices. Journal of Clinical Dentistry. 2010;21:101-104.

11. de Oliveira SM, Torres TC, Pereira SL, Mota OM, Carlos MX. Effect of a dentifrice containing Aloe vera on plaque and gingivitis control: A double-blind clinical study in humans. Journal of applied oral science. 2008;16(4):293-296.

12. Radafshar G, Mahboob F, Kazemnejad E. A study to assess the plaque inhibitory action of herbal-based toothpaste: a double blind controlled clinical trial. Journal of Medicinal Plants Research. 2010;4(12): 1182-1186.

13. Tatikonda A, Debnath S, Chauhan VS, Chaurasia VR, Taranath M, Sharma AM. Effects of herbal and non-herbal toothpastes on plaque and gingivitis: $A$ clinical comparative study. Journal of International Society of Preventive \& Community Dentistry. 2014;S2:126-9.

14. Ahmad $\mathrm{H}$, Ahamed $\mathrm{N}$. Therapeutic properties of meswak chewing sticks: A review. African Journal of Biotechnology. 2012;11(83):14850-14857.

15. Singh K, Singh P, Oberoi G. Comparative studies between herbal toothpaste (dantkanti) and non-herbal tooth paste. International Journal of Dental Research. 2016;4(2):53-56.

16. Woese CR, Fox GE. Phylogenetic structure of the prokaryotic domain: The primary kingdoms. Proceedings of the National Academy of Sciences. 1977; 74(11):5088-5090.

17. McCormack MG, Smith AJ, Akram AN, Jackson M, Robertson D, Edwards $G$. Staphylococcus aureus and the oral cavity: An overlooked source of carriage and infection? American Journal of Infection Control. 2015;43(1):35-37. 
18. Minnaganti VR, Patel PJ, lancu D, Schoch PE, Cunha BA. Necrotizing fasciitis caused by Aeromonas hydrophila. Heart \& Lung: The Journal of Acute and Critical Care. 2000;29(4):306-308.

19. Oliveira ACD, Maluta RP, Stella AE, Rigobelo EC, Marin JM, Ávila FAD. Isolation of Pseudomonas aeruginosa strains from dental office environments and units in Barretos, state of São Paulo, Brazil, and analysis of their susceptibility to antimicrobial drugs. Brazilian Journal of Microbiology. 2008;39(3):579-584.

20. Haukioja A. Probiotics and oral health. European Journal of Dentistry. 2010;4(3):348-55.

21. Goh SY, Khan SA, Tee KK, Kasim NHA, Yin WF, Chan KG. Quorum sensing activity of Citrobacter amalonaticus L8A, a bacterium isolated from dental plaque. Scientific reports 6. 2016;6:20702.

22. Szymańska J. Bacterial contamination of water in dental unit reservoirs. Annals of Agricultural and Environmental Medicine. 2007;14(1):137-40.

23. Pimenta-Rodrigues MV, Fusco-Almeida AM., Bertoni BW, Pietro RCLR. Assessment of genetic relationship between Klebsiella pneumoniae and Klebsiella oxytoca samples isolated from a dental office. Journal of Venomous Animals and Toxins including Tropical Diseases. 2008;14(4):703-718.

24. Lal S, Singhrao SK, Achilles-Day UE, Morton LH, Pearce M, Crean S. Risk assessment for the spread of Serratia marcescens within dental-unit waterline systems using vermamoeba vermiformis. Current microbiology. 2015; 71(4):434-442.

25. Norman O Harris, Garcia-Godoy F. Primary preventive dentistry. Upper Saddle River, NJ: Pearson Education. $6^{\text {th }}$ edition; 2004.

26. Miller, Chris $H$. Infection control and management of hazardous materials for the dental team. $3^{\text {rd }}$ edition; 2004.

27. Kuldeep Singh K, Pooja Singh, Gurpreet Oberoi. Comparative studies between herbal toothpaste (dantkanti) and nonherbal tooth paste. International Journal of Dental Research. 2016;4(2):53-56.

28. Jenner $F$, Jaleel VA, Kulshrestha $R$, Maheswar G, Rao PK, Kranthi J. Evaluating the antimicrobial activity of commercially available herbal toothpastes on microorganisms associated with diabetes mellitus. Journal of contemporary dental practice. 2013;14(5):924-929.

29. Shibani Vyas, Sadanand Kulkarni. Patanjali Dant Kanti: Is it worth all the hype!? Comparative evaluation with other herbal dentifrices for efficacy against S.mutans. International Journal of Applied Research. 2018;4(2):212-215.

30. Anitha Thomas, Shailaja Raj, Venkataramana J. Antimicrobial activity of TiO2 nanoparticles against Microbial Isolates causing dental plaques. International Journal of Bioassays. 2014;3(06):3106-3110.

31. Smith AJ, Robertson D, Tang MK, Jackson MS, MacKenzie D, Bagg J. Staphylococcus aureus in the oral cavity: A three-year retrospective analysis of clinical laboratory data. British Dental Journal. 2003;195(12):701-703.

(c) 2020 Raj et al.; This is an Open Access article distributed under the terms of the Creative Commons Attribution License (http://creativecommons.org/licenses/by/4.0), which permits unrestricted use, distribution, and reproduction in any medium, provided the original work is properly cited. 